\title{
Evaluasi Kelahiran Pedet Sapi Perah di Balai Besar Pembibitan Ternak Unggul dan Hijauan Pakan Ternak Baturraden
}

\section{Calving Evaluation of Dairy Cattle in Balai Besar Pembibitan Ternak Unggul dan Hijauan Pakan Ternak Baturraden}

\author{
N. U. Aprily, P. Sambodho dan D. W. Harjanti* \\ Fakultas Peternakan dan Pertanian Universitas Diponegoro, Semarang, 50275 \\ E-mail: dianharjanti@undip.ac.id \\ (Diterima: 18 November 2015 ; Disetujui: 13 Januari 2016)
}

\begin{abstract}
ABSTRAK
Tujuan penelitian untuk mengevaluasi kelahiran pedet sapi perah dengan indikator jumlah kelahiran jantan dan betina, lama kebuntingan dan bobot lahir sapi yang dipelihara oleh Balai Besar Pembibitan Ternak Unggul Hijauan Pakan Ternak (BBPTU HPT) Baturraden, Purwokerto. Penelitian dilaksanakan bulan April 2015. Materi penelitian adalah data rekording kelahiran sapi perah mulai dari tahun 2010 hingga April 2015. Data rekording memuat informasi nomor identitas pedet, tanggal IB (Inseminasi Buatan), tanggal kelahiran, bobot lahir dan jenis kelamin pedet. Parameter yang diamati adalah jumlah kelahiran dan kegagalan lahir, bobot lahir dan jenis kelamin. Sedangkan lama kebuntingan dihitung mulai dari tanggal IB terakhir sampai tanggal lahir pedet. Analisis data kelahiran pedet dilakukan dengan deskriptif. Data bobot lahir dan lama kebuntingan dilakukan uji normalitas Shapiro-Wilk menggunakan software SPSS 16.0 kemudian dilanjutkan dengan uji T-Test. Hasil penelitian menunjukkan bahwa jumlah kelahiran dari tahun 2010 sampai April 2015 sebanyak 822 ekor, yang terdiri dari pedet jantan sebanyak 424 ekor (51,58 \%) dan betina 398 ekor (48,42\%). Peristiwa kegagalan lahir sebanyak 112 ekor karena abortus, freemartin, distokia dan stillbirth. Bobot lahir pedet jantan dan betina relatif sama $(\mathrm{P}>0,05)$ yaitu rata-rata $43,34 \mathrm{~kg}$ (jantan) dan 40,39 $\mathrm{kg}$ (betina). Lama kebuntingan relatif sama ( $>0,05)$, rata-rata lama kebuntingan yaitu 277 hari (jantan) dan 278 hari (betina). Kesimpulannya adalah; kelahiran pedet betina perlu ditingkatkan melalui penurunan angka kematian atau kegagalan lahir.
\end{abstract}

Kata kunci: pedet, sapi perah, kelahiran, bobot lahir, lama kebuntingan

\section{ABSTRACT}

The aim of this research was to evaluate the birth of dairy cattle using reproduction recording in Balai Besar Pembibitan Ternak Unggul Hijauan Pakan Ternak (BBPTU HPT) Baturraden, Purwokerto. The research was conducted in April 2015. The research was conducted in April 2015 using breeding records from 2010 until April 2015. The recording data contained the date of partum, calves ear tag, the date of artificial insemination (AI) delivery, birth weight and sex of the calves. Observed parameters consisted of both total of normal and failure of birth, weight of birth and sexes. The length of gestation was calculated from the last AI delivery date to partum. The number of calves were analyzed using descriptive approaceh. However, the birth weight of calves and gestation length were analyzed by using Shapiro-Wilk normality test and T-Test with SPSS 16.0 software support. The results showed that the total of normal birth from 2010 until April 2015were 822 head of calves, consisting of 424 male calves $(51.58 \%)$ and 398 female calves $(48.42 \%)$. There were 112 cases of prenatal and postnatal mortality due to abortus, freemartin, distochiia and stillbirth. Mean of birth weight of male calves (43.34 kg) and female calves $(40.39 \mathrm{~kg})$ was relatively similar $(P>0.05)$. Moreover, the length of gestation was also similar $(P>0.05)$ where gestation periode for male calves 277 days and female calves 278 days. Therefore, BBPTU HPT Baturraden should increase the number of female calves by decreasing the reproductive problems.

Keywords: calves, dairy cattle, birth, birth weight, length of gestation 


\section{PENDAHULUAN}

Peningkatan produksi susu menjadi pokok utama untuk memenuhi kebutuhan masyarakat akan protein hewani. Kesadaran akan kebutuhan protein hewani yang semakin meningkat sejalan dengan meningkatnya taraf hidup masyarakat belum mampu tercukupi dengan keadaan produksi susu sapi di Indonesia yang masih rendah. Peran usaha pembibitan guna pengembangan ternak sapi perah menjadi semakin penting seiring semakin meningkatnya kebutuhan susu sebagai bahan baku dan bahan makanan sumber protein hewani.

Balai Besar Pembibitan Ternak Unggul dan Hijauan Pakan Ternak yang merupakan salah satu Unit Pelaksana Teknis (UPT) dibawah Direktorat Jenderal Peternakan Kementerian Pertanian adalah satu-satunya UPT Pembibitan yang memiliki tugas dan tanggung jawab pengembangan sapi perah di Indonesia. Diharapkan Balai Besar Pembibitan Ternak Unggul dan Hijauan Pakan Ternak mampu meningkatkan kinerja berupa peningkatan pembibitan sapi perah dan produksi susu.

Peranan usaha pembibitan dalam meningkatkan produksi sejalan dengan peranan manajemen yang baik. Langkah identifikasi ternak dan evaluasi penerapan manajemen perlu dilakukan sebagai gambaran keberlangsungan manajemen produksi yang baik agar kontinyu dan menguntungkan. Kelahiran pedet sapi perah menjadi faktor yang penting dalam aktivitas produksi usaha peternakan sapi perah baik produksi bibit maupun produksi susu sehingga perlu adanya evaluasi kelahiran pedet sapi perah sebagai penunjang manajemen produksi yang baik. Produktivitas ternak yang merupakan tolak ukur dari keberhasilan perusahaan dibidang peternakan bergantung pada keberhasilan reproduksi ternaknya (Rasad, 2009). Produksi susu secara fisiologis merupakan sejumlah susu yang disekresikan kelenjar ambing induk ternak sapi perah. Induk sapi perah dengan kondisi tubuh dan bobot lahir anak sapi perah yang baik akan mempengaruhi produksi susu yang optimal
(Purwanto et al., 2013). Bobot lahir pedet adalah salah satu yang dapat mempengaruhi penampilan pedet menjadi informasi pertama terhadap potensi perkembangan sapi terhadap produktivitasnya (Oluwumi dan Saloko, 2010). Jenis kelamin dan musim kelahiran pedet termasuk faktor yang mempengaruhi lama kebuntingan selain yang sudah banyak dilaporkan (Arman, 2012).

Tujuan penelitian ini adalah mengevaluasi kelahiran pedet sapi perah yang dipelihara oleh Balai Besar Pembibitan Ternak Unggul dan Hijauan Pakan Ternak (BBPTU HPT) Baturraden, Purwokerto. Hasil penelitian diharapkan dapat memberikan informasi dan pembelajaran untuk pengembangan usaha ternak sapi dan peningkatan produktivitas sapi perah baik dilokasi penelitian ataupun lokasi lain dengan kemiripan kondisi pemeliharaan terutama dalam mengevaluasi kelahiran.

\section{METODE}

Penelitian dilaksanakan pada bulan April 2015 di Balai Besar Pembibitan Ternak Unggul dan Hijauan Pakan Ternak (BBPTU HPT) Baturraden. Materi yang digunakan untuk penelitian adalah data rekording kelahiran pedet dari tahun 2010 sampai April 2015. Pengambilan data dilakukan dengan mengumpulkan catatan kelahiran berupa informasi ear tag atau nomor identitas pedet, tanggal Inseminasi Buatan(IB), tanggal kelahiran, kode strawatau nama pejantan, bobot lahir dan jenis kelamin pedet.

Penelitian dilakukan dengan mengumpulkan informasi dan data rekording pada saat penelitian dilakukan. Pengumpulan data rekording dilakukan sebagai data pokok untuk selanjutnya dianalisis secara deskritif dan statistik yang terdiri dari data jumlah kelahiran dan kegagalan lahir, bobot lahir dan jenis kelamin. Lama kebuntingan dilihat dari jarak antara pelaksanaan IB terakhir dengan tanggal kelahiran pedet.Mengamati catatan bobot kelahiran pedet betina dan jantan dari data yang telah dikumpulkan. Analisis data jumlah kelahiran pedetjantan 
dan pedet betina dilakukan dengan deskriptif sedangkan data bobot lahir dan lama kebuntingan dengan melakukan uji normalitas Shapiro-Wilk menggunakan software SPSS 16.0 kemudian jika hasilnya menunjukkan data normal dilanjutkan dengan uji T-Test. Parameter yang diamati dalam penelitian ini yaitu data bobot badan dan lama kebuntingan dari kelahiran sapi perah jantan dan betina mulai dari tahun 2010 sampai April 2015.

\section{HASIL DAN PEMBAHASAN}

\section{Kelahiran Pedet di BBPTU HPT Baturraden}

Hasil penelitian menunjukkan data kelahiran setiap tahunnya mulai dari tahun 2010 hingga 2013 mengalami kenaikan dan mengalami penurunan pada tahun 2014. Pada tahun 2015 angka kelahiran cukup kecil karena catatan kelahiran belum sepenuhnya satu tahun hanya sampai bulan April. Data kelahiran setiap tahunnya dapat ditampilkan pada Tabel 1.

Dari data jumlah kelahiran di atas, dapat dilihat bahwa total kelahiran pedet di BBPTU HPT Baturraden dari tahun 2010 sampai April 2015 sebanyak 822 ekor yang terdiri dari 424 ekor pedet jantan dan 398 ekor pedet betina. Keadaan induk menjadi faktor banyaknya jumlah pedet yang lahir. Tercatat dalam data existing balai yang dikeluarkan oleh BBPTU HPT Baturraden, jumlah induk betina sapi perah mulai tahun 2010 sebanyak 158 ekor dan bertambah sampai bulan April 2014 tercatat sebanyak
605 ekor induk (Ditjennak, 2015). Faktor jumlah induk sangat berpengaruh terhadap jumlah kelahiran pedet. Muslim et al. (2012) menyatakan bahwa banyaknya jumlah pedet yang dihasilkan disebabkan banyaknya jumlah pedet yang bertahan hidup karena faktor induk itu sendiri dan lingkungan atau faktor genetik dan non genetik.

Berdasarkan Tabel 1 menunjukkan bahwa jumlah kelahiran dari tahun 2010 sampai April 2015 di BBPTU HPT Baturraden sebanyak 822 ekor, kelahiran pedet di BBPTU HPT Baturraden menunjukkan jumlah kelahiran yang berjenis kelamin jantan lebih besar daripada kelahiran pedet yang berjenis kelamin betina yaitu 424 ekor $(51,58 \%)$ jantan dan 398 ekor $(48,42 \%)$ betina. Besarnya peluang terbentuknya kombinsai XY (individu jantan) dan kombinasi XX (individu betina) adalah sama yaitu sebesar 50\%:50\% yang pada kenyataannya sering mengalami pergeseran nilai imbangan yang terjadi karena pembuahaan maupun pada perkembangannya. Secara teoritis disampaikan bahwa seharusnya penyatuan ovum haploid $\mathrm{X}$ dengan sperma haploid $\mathrm{X}$ atau Y menghasilkan 50\% jantan dan 50\% betina. Faktor yang dapat menyebabkan rasio kelamin antara lain tingkat seleksi, musim, umur dan paritas induk betina dan pejantan yang digunakan (Prasojo et al., 2010). Firman et al. (2010) menyatakan bahwa rasio kelahiran 50:50 antara kelahiran jantan dan kelahiran betina pada sapi perah dapat memperhitungkan peluang ternak

Tabel 1. Data kelahiran pedet sapi perah di BBPTU HPT Baturraden.

\begin{tabular}{|c|c|c|c|c|}
\hline \multirow{2}{*}{ Tahun } & \multicolumn{2}{|c|}{ Jenis kelamin } & \multirow{2}{*}{ Jumlah lahir } & \multirow{2}{*}{ Kegagalan kelahiran } \\
\hline & $\operatorname{Jantan}\left(0^{\Uparrow}\right)$ & Betina $(q)$ & & \\
\hline \multicolumn{5}{|c|}{ 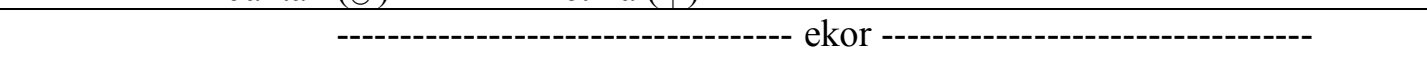 } \\
\hline 2010 & 24 & 20 & 49 & 5 \\
\hline 2011 & 67 & 57 & 134 & 10 \\
\hline 2012 & 91 & 86 & 200 & 23 \\
\hline 2013 & 116 & 116 & 367 & 35 \\
\hline 2014 & 111 & 101 & 245 & 30 \\
\hline $2015 *$ & 15 & 18 & 42 & 9 \\
\hline Total & $424(51,58 \%)$ & $398(48,42 \%)$ & 822 & 112 \\
\hline
\end{tabular}

Keterangan : * Data sampai dengan bulan April 2015. 


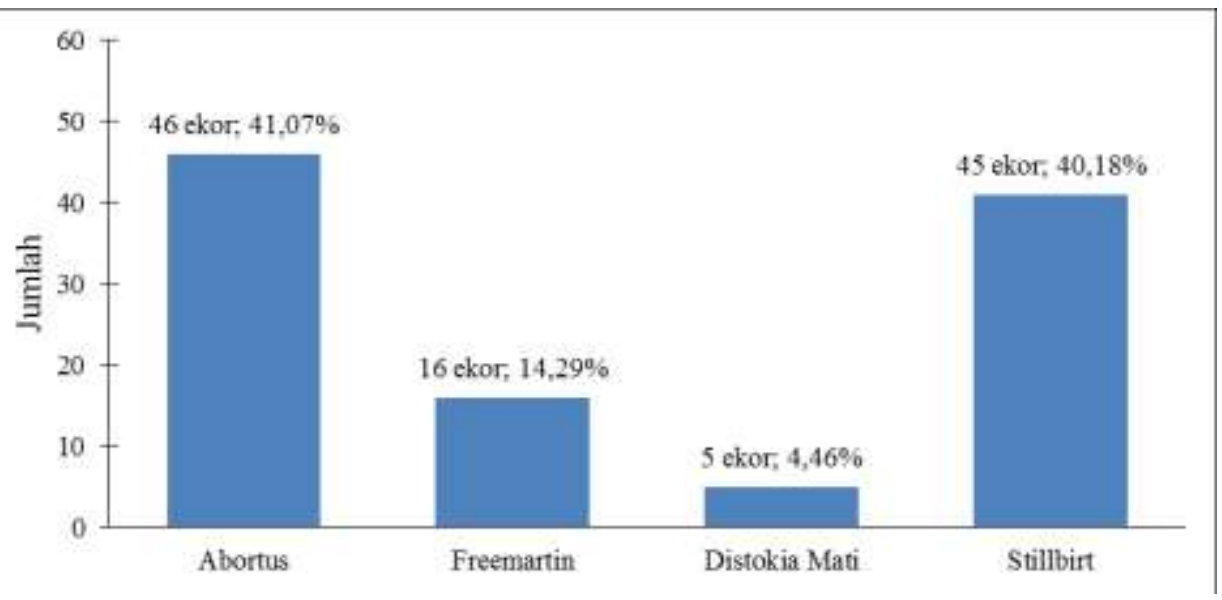

Gambar 1. Kegagalan Lahir dan Kematian Pedet Pasca Lahir.

sebagai ternak pengganti (replacement stock).

Sistem perkawinan sapi perah yang diterapkan di BBPTU HPT Baturraden adalah dengan sistem InseminasiBuatan (IB). Menurut Berry dan Cromie (2007), perkawinan yang dilakukan dengan sistem IB meningkatkan peluang untuk mendapatkan anak jantan dibandingkan anak betina. BBPTU HPT Baturraden yang berperan penting terhadap pengembangan pembibitan belum menerapkan metode sexing dalam mengawinkan ternak yang dipelihara sebagai langkah memperbesar peluang dengan kelahiran betina sebagai penyedia bibit dan produksi susu. Darminto et al. (2009) menyatakan bahwa untuk memperoleh keturunan dengan jenis kelamin yang diinginkan dapat dilakukan perkawinan metode sexing dengan menggunakan semen hasil pemisahan sel spermatozoa pembawa kromosaom penentu jenis kelamin (sexing spermatozoa). Dengan metode ini, rasio spermatozoa pembawa kromosom X (betina) dan $\mathrm{Y}$ (jantan) yang awalnya 50:50 dapat diubah menjadi kurang lebih 70:30.

Kelahiran di BBPTU HPT Baturraden tercatat adanya kegagalan kelahiran dan kematian pedet pasca lahir. Jumlah kegagalan kelahiran dan kematian pedet pasca lahir dari tahun 2010 sampai April 2015 yaitu 112 ekor yang disebabkan karena beberapa faktor. Dari Gambar 1 diatas, dapat dilihat bahwa angka kegagalan kelahiran dan kematian pedet pasca lahir dari tahun 2010 sampai April 2015 disebabkan karena abortus (keguguran), freemartin (abnormalitas kembar jantan dan betina), distokia (kesulitan dalam kelahiran) dan stillbirth atau lahir mati (yang disebabkan terlambat mendapat kolostrum, pedet abses dipersendian, premature dan gangguan syaraf atau leher tremor serta sebab lain yang belum diketahui). Abortus merupakan gangguan reproduksi pada ternak yaitu pengeluaran fetus sebelum akhir masa kebuntingan. Hal yang dapat menyebabkan abortus adalah defisiensi makanan dan kelaparan yang parah pada induk bunting (Toelihere, 1985). Distokia adalah gangguan reproduksi yang menyebabkan ternak kesulitan melahirkan. Kejadian distokia biasanya terjadi pada sapi dara yang baru pertama kali melahirkan (Schuenemann, 2012). Penyebab distokia umumnya dikarenakan ukuran fetus yang besar, posisi fetus yang abnormal, dilatasi serviks yang tidak sempurna, terjadinya kondisi uterus yang tidak kontraksi atau karena kelelahan, torsio uterus dan fetus yang kembar (Whittier, 2009). Persentase kegagalan kelahiran dan kematian pedet pasca kelahiran di BBPTU HPT Baturraden berkisar $12 \%$ atau sebanyak 112 ekor dari total kebuntingan sebanyak 935 dan kelahiran normal sebanyak 822 ekor. Hasil serupa juga dilaporkan oleh Firman et al. (2010) bahwa persentase tingkat kegagalan kelahiran pada sapi perah pada beberapa penelitian berkisar antara 10-15\%. 
Kegagalan kelahiran tersebut diantaranya disebabkan oleh kematian embrio, abortus dan mumifikasi fetus (Susilo, 2005). Kesulitan kelahiran sering dialami pada sapi terutama sapi-sapi yang berukuran besar seperti sapi FH, sapi-sapi yang selalu dikandangkan terus-menerus, masa kebuntingan yang terlalu lama, kelahiran kembar, infeksi uterus kematian foetus dan lain sebagainya. Menurut Yulyanto et al. (2014), sapi yang belum pernak melahirkan atau baru akan melahirkan pertama kali lebih besar menerima resiko kegagalan kelahiran dibandingkan dengan sapi yang sudah pernah melahirkan pedet sebelumnya.

\section{Bobot Lahir Pedetdi BBPTU HPT Baturraden}

Hasil penelitian menunjukan bahwa rata-rata bobot lahir pedet jantan dan pedet betina mulai dari tahun 2010 sampai April 2015 yaitu 43,34 kg dan 40,39 kg. Bobot lahir merupakan hal yang penting sebagai pertumbuhan pedet sapi. Sapi dengan bobot badan lebih besar dan dilahirkan secara normal akan lebih mampu mempertahankan kehidupannya. Bobot lahir anak ditentukan oleh beberapa faktor diantaranya, bangsa induk, jenis kelamin anak, lama bunting induk, umur atau paritas induk dan makanan induk selama masa kebuntingan (Prasojo, 2010). Data rata-rata bobot lahir setiap tahunnya antara pedet jantan dan betina mulai tahun 2010 - April 2015 dapat dilihat pada Tabel 2 .

Bobot lahir pedet di BBPTU HPT Baturraden berkisar 40,39 - 43,34 kg. Hal ini disebabkan karena pemberian pakan dan manajemen pakan yang diterapkan sudah baik. Pemberian pakan di BBPTU HPT Baturraden dilakukan dengan pemberian pakan hijauan berupa rumput dan legume yang ditanam dilahan BBPTU HPT Baturraden serta pemberian konsentrat yang sesuai dengan pertumbuhan ternak sapi perah yang dipelihara. Menurut Purwanto et al. (2013), tingginya bobot lahir pedet disebabkan karena pemeliharaan yang baik dan pemberian pakan dengan kualitas yang maksimal. Kekurangan pakan yang dialami oleh ternak bunting dapat mengganggu pertumbuhan embrio serta kematian fetus dalam kandungan atau bila dapat melahirkan akan terdapat kelainan pada pedet (Anggorodi, 1979).

Dari hasil analisis data menunjukkan $(\mathrm{P}>0,05)$ bahwa rata-rata bobot lahir antara pedet jantan dan pedet betina tidak berbeda nyata $(\mathrm{P}>0,05)$. Rata-rata bobot lahir antara pedet jantan dan pedet betina yang tidak berbeda nyata dapat disebabkan karena ternak yang dipelihara di BBPTU HPT Baturraden memiliki faktor genetik yang unggul dan nutrien dari pakan yang diberikan dapat diserap optimal oleh fetus baik jantan maupun betina. Pernyataan yang berbeda disampaikan oleh Campbell dan Lasley (1969) yang menyatakan bahwa pada umur kebuntingan yang sama fetus jantan lebih cepat pertumbuhannya daripada fetus betina, hal ini disebabkan karena fetus jantan lebih aktif dalam menyerap makanan induk saat bunting dibandingkan fetus betina. Menurut Salisbury dan Vandemark (1985), perbedaaan bobot lahir dapat berbeda disebabkan oleh perbedaan genetik setiap induk dan bobot masing-masing induk sapi

Tabel 2. Data Rata-rata Bobot Lahir Jantan dan Betina Tahun 2010-2015.

\begin{tabular}{ccc}
\hline \multirow{2}{*}{ Tahun } & \multicolumn{2}{c}{ Rata-rata bobot lahir $(\mathrm{kg})$} \\
\cline { 2 - 3 } & Jantan $\left(\mathrm{O}^{\top}\right)$ & Betina $($ ( $)$ \\
2010 & 47,40 & 41,90 \\
2011 & 43,70 & 40,87 \\
2013 & 42,73 & 40,60 \\
2014 & 40,33 & 39,43 \\
2015 & 41,43 & 39,34 \\
Rata-rata & 44,47 & 40,22 \\
\hline
\end{tabular}

Keterangan : tidak berbeda nyata $(\mathrm{P}>0,05)$ 
yang melahirkan maupun pejantannya. Bobot lahir anak sapi bervariasi menurut bangsanya dan diantara bangsa itu sendiri dan diantara induk dengan induk yang lain.

Ukuran besar induk betina lebih berpengaruh terhadap ukuran besar anak sapi daripada ukuran besar induk pejantan. Ratarata bobot lahir pedet jantan dan pedet betina di BBPTU HPT Baturraden selisih sebesar 2,95 kg. Menurut Hasriati (2001), bobot lahir pedet jantan dibanding dengan pedet betina lebih besar 1-5 kg. Hal yang dapat mempengaruhinya adalah bangsa induk, jenis kelamin anak, lama bunting induk, umur atau paritas induk dan makanan induk selama mengandung. Bobot lahir dan jenis kelamin memiliki hubungan positif yaitu bahwa anak sapi yang memiliki bobot yang lebih besar cenderung berjenis kelamin jantan (Prasojo, 2010).

Menurut Speidel et al. (2007), perbedaan bobot lahir pedet sapi dapat disebabkan adanya depresi nutrien pakan yang disebabkan perubahan iklim, serta perubahan musim yang berdampak kepada sapi betina dan pedetnya untuk mengekspresikan perbedaan genetik secara langsung. Lokasi BBPTU HPT Baturraden khususnya pada area Farm Tegalsari tempat penelitian dilaksanakan berada pada ketinggian sekitar 600mdpl dengankeadaan iklim yang sejuk dan cocok untuk peternakan sapi perah. Temperatur berkisar $18-30^{\circ} \mathrm{C}$, kelembaban berkisar antara 70 $80 \%$ dan curah hujan berkisar 3.000 - 3.500 $\mathrm{mm} /$ th.Lingkungan merupakan faktor yang berpengaruh cukup besar terhadap penampilan produktivitas ternak. Bangsa ternak yang tergolong genetik unggul tidak akan optimal apabila faktor lingkungan tidak sesuai dan lingkungan diprediksi berpengaruh pada kondisi induk bunting (Muslim et al., 2012).

\section{Lama Kebuntingan Sapi Perah di BBPTU HPT Baturraden}

Hasil penelitian menunjukan bahwa rata-rata lama kebuntingan yang melahirkan pedet jantan dan pedet betina mulai dari tahun 2010 sampai April 2015 yaitu 277 hari dan 278 hari. Data rata-rata lama kebuntingan setiap tahunnya dapat dilihat pada Tabel 3.

Dari data diatas menunjukkan bahwa rata-rata lama kebuntingan jantan dan betina masing-masing adalah 277 hari dan 278 hari. Rata-rata lama kebuntingan sapi perah di BBPTU HPT Baturraden tidak berbeda jauh dengan pendapat Salisbury dan Vandemark (1985), yang menyatakan bahwa rata-rata lama kebuntingan untuk sapi perah jenis Friesien Holstein adalah 278,9 hari. Menurut Arman (2006) lama kebuntingan pada sapi perah pada bangsa Bos Taurus rata-rata 279 hari. Hasil penelitian yang dilakukan oleh Sulistyowati et al. (2009) menunjukkan ratarata lama kebuntingan 275 hari yang pada umumnya lama kebuntingan berada disekitar 278-288 hari.

Hasil analisis data menunjukkan bahwa rata-rata lama kebuntingan yang melahirkan pedet antara pedet jantan dan

Tabel 3. Data rata-rata lama kebuntingan.

\begin{tabular}{ccc}
\hline \multirow{2}{*}{ Tahun } & \multicolumn{2}{c}{ Lama kebuntingan (hari) } \\
\cline { 2 - 3 } & Jantan $\left(\hat{\delta}^{\wedge}\right)$ & Betina $($ (q) \\
\hline 2010 & 278 & 279 \\
2011 & 279 & 278 \\
2012 & 277 & 278 \\
2013 & 276 & 276 \\
2014 & 277 & 277 \\
2015 & 279 & 279 \\
Rata-rata & 277 & 278 \\
\hline
\end{tabular}

Keterangan : tidak berbeda nyata $(\mathrm{P}>0,05)$ 
pedet betina tidak berbeda nyata $(\mathrm{P}>0,05)$ yang menandakan bahwa perbedaan antara rata-rata lama kebuntingan jantan dan betina tidak berbeda $(\mathrm{P}>0,05)$. Penelitian yang sama dilakukan oleh Arman (2006) juga menunjukkan hasil nilai statistik tidak terdapat perbedaan nyata antara pedet jantan dan betina terhadap lama kebuntingan. Menurut Prasojo (2010), lama kebuntingan ditentukan oleh faktor maternal, lingkungan dan fetus. Pengaruh fetus antara lain yaitu jenis kelamin fetus, kelenjar adrenal dan hipofise serta ukuran fetus. Pada ternak sapi lama kebuntingan beragam menurut bangsa, jenis kelamin anak yang dikandung dan beberapa faktor lain. Adapun faktor lain yaitu, umur induk, musim, sifat-sifat khusus pewarisan pada bangsa itu dan letak geografis (Salisbury dan Vandemark, 1985).

\section{KESIMPULAN}

Jumlah kelahiran pedet betina perlu ditingkatkan dan angka kematian atau kegagalan lahir harus ditekan.Diperlukan introduksi teknologi untuk meningkatkan jumlah kelahiran pedet betina, salah satunya dengan metode sexing.

\section{DAFTAR PUSTAKA}

Anggorodi, R. 1979. Ilmu Makanan Ternak. Cetakan kedua. PT. Gramedia. Jakarta.

Arman, C. 2006. Faktor-faktor yang mempengaruhi lama kebuntingan pada sapi hissar Sumbawa. Jurnal Ilmuilmu Peternakan. 9(4) : 235-242.

Arikunto, S. 2005. Manajemen Penelitian. Rineka Cipta. Jakarta.

Berry,D. P. and A. R. Cromie. 2007. Artificial insemination increases the probability of a male calf in dairy and beer cattle. Journal Theriogenology. 67(2): 346-352.

Campbell, J. R. and J. F. Lasley. 1985. The Scince of Animal that Serve Humanity. Mc Graw Hill Inc., New York.

Darminto, E., Triwulaningsih., A. Anggraeni., dan Y. Widiawati. 2009.
Aplikasi inovasi teknologi peternakan kerbau lokal. Prosiding Seminar dan Lokakarya Nasional Kerbau. Hal.1324.

Ditjennak. 2015.http://bbptusapiperah. ditjennak.pertanian.go.id/statis-14existingbalai.html. (Diakses pada tanggal 14 September 2015).

Firman, A., S. B. K. Prajoga., dan Hermawan. 2010. Peran usaha pembibitan dalam pengembangan ternak sapi perah di Indonesia. Jurnal Ilmu Ternak. 10(1): 7-13.

Muslim, K. N., H. Nugroho., dan T. Susilowati. 2012. Hubungan antara bobot badan induk dan bobot lahir pedet sapi Brahman Cross pada jenis kelamin yang berbeda. Jurnal Ilmuilmu Peternakan. 23(1) : 18-24.

Prasojo, G., I. Arifiantini., dan K. Muhammad. 2010. Korelasi antara lama kebuntingan, bobot lahir dan jenis kelamin pedet hasil inseminasi buatan pada sapi bali. Jurnal Veteriner. 11(1): 41-45.

Purwanto, H., A.T. Sudewo dan S. Utami. 2013. Hubungan antara bobot lahir dan body condition score (BCS) periode kering dengan produksi susu di BBPTU sapi perah Baturraden. Jurnal Ilmiah Peternakan. 1(1): 134141.

Salisbury, G.W. dan N.L. Vandemark. 1985. Fisiologi Reproduksi dan Inseminasi Buatan pada Sapi. Gajah Mada University Press. Yogyakarta.

Schuenemann, G. M. 2012. Calving Manajement in Dairy Herds: Timing of Intervention and Stillbirth. Ohio (USA): The Ohio State University.

Sulistyowati, E., E. Kusuwadi., L. Sutarno., danD. Tampubolon. 2009. Penampilan reproduksi sapi perah FH (Friesh Holland) dan pertumbuhan pedetnya pada umur 1-3 bulan (studi kasus di Desa Air Duku dan Desa Air Putih Kali Bandung, Selupu Rejang, Rejang Lebong, Bengkulu). Jurnal Sains Peternakan Indonesia. 4(1): 21-26.

Susilo, T. 2005. Efisiensi Reproduksi Program Inseminasi Buatan Terhadap 
Sapi Lokal pada Daerah Lahan Basah dan Kering di Kabupaten Magelang Provinsi Jawa Tengah. Program Studi Magister Ilmu Ternak Program Pascasarjana Universitas Diponegoro, Semarang. (Tesis).

Speidel, S. E., R. M.Enns., and D. J. Garrick. 2007. Weaning weight inheritance in environments classified by materal body weight change. Journal Animal Science. 85(1): 610-617.

Toelihere, MR. 1985. Ilmu Kebidanan pada Ternak dan Kerbau. Universitas Indonesia Press. Jakarta.
Whittier, W. D., N. M. Currin.,J. F. Currin., and J. B.Hall. 2009. Calving Emergencies in Beef Cattle: Identification and Prevention. Virginia Cooperation Extension Publication. 400-018.

Yulyanto, C. A., T. Susilawati., dan N. Ihsan. 2014. Penampilan reproduksi sapi peranakan ongole (PO) dan sapi peranakan limosin di Kecamatan Sawoo Kabupaten Ponorogo dan Kecamatan Tugu Kabupaten Trenggalek. Jurnal Ilmu-ilmu Peternakan. 24(2): 49-57. 